\title{
Effects of Tax-Based Saving Incentives on Contribution Behavior: Lessons from the Introduction of the Riester Scheme in Germany
}

\author{
Swen Kuper, Thomas-Patrick Schmidt \\ Ruhr-University Bochum, Bochum, Germany \\ Email: swen.kuper@rub.de
}

How to cite this paper: Kuper, S. and Schmidt, T.-P. (2016) Effects of Tax-Based Saving Incentives on Contribution Behavior: Lessons from the Introduction of the Riester Scheme in Germany. Modern Economy, 7, 1198-1222. http://dx.doi.org/10.4236/me.2016.711117

Received: August 17, 2016

Accepted: August 24, 2016

Published: September 29, 2016

Copyright $\odot 2016$ by authors and Scientific Research Publishing Inc. This work is licensed under the Creative Commons Attribution International License (CC BY 4.0). http://creativecommons.org/licenses/by/4.0/

\begin{abstract}
This paper analyzes the effects of tax-based saving incentives on contribution behavior in Germany (Riester Pension). Using tax reform and inflation, the effect of the tax price on the decision of whether or not to contribute is analyzed. Our central estimate implies a local average elasticity of the contribution decision of -2.36 . In addition, using shifts in price kinks over time, we show graphical evidence of the decision on how much to contribute. Our results show that taxpayers adjust their savings immediately if the subsidized amount increases. Consequently, the government has control over the contribution behavior on both margins by setting tax-based saving incentives.
\end{abstract}

\section{Keywords}

Subsidized Pension, Riester Scheme, Personal Income Tax, Retirement Savings

\section{Introduction}

Old age provisions can be financed as a pay-as-you-go or fully funded system. European countries usually have pay-as-you-go systems where current contributions are used to finance current provisions. Rising life spans and declining birth rates of the last decades have been generating a funding gap. Generally, this could be addressed by reforming the pay-as-you-go system itself (e.g., increasing contributions, decreasing provisions, or through governmental grants) or by reforming the whole old age provision system.

In the last decades, several European governments have reformed their retirement systems. From a governmental perspective, there are three pillars of old age provisions. Pillar 1, the traditional pay-as-you-go system, has been extended by Pillar 2, occupa- 
tional pension schemes, and Pillar 3, private pension schemes. Private pension schemes are voluntary and generally subsidized [1]. Consequently, the success of retirement reform depends on the acceptance of private pensions and, therefore, on the effects of tax-based saving incentives on contribution behavior.

Germany introduced the Riester Scheme in 2002. The main issue has been the financing gap of the pay-as-you-go system. Although the contribution rate of Pillar 1 is expected to increase from $19.9 \%$ in 2008 to $21.4 \%$ in 2028 , the replacement rate of the German statutory pension insurance is expected to decline from $50.5 \%$ in 2008 to $44.4 \%$ in 2028 [2]. Because employees are mandatory members of this insurance, they are faced by an old age provision gap. The governmental goal is that employees overcome this gap by contributing $4 \%$ of their gross wage to a private pension. That is why Germany grants one of the most generous tax subsidies for private pensions [3] [4].

Due to the subsidy, the Riester Pension is superior to non-funded saving accounts, especially for families with children and low income [5]. Studies investigating the probability of participating in a Riester Pension found that the number of children, income, and age were the dominating factors [6]-[8]. However, as with other voluntary private pensions, it is not clear if the introduction of the Riester Scheme in 2002 has had an impact on the overall saving rate of households [9] [10]. Consequently, the introduction of the Riester Scheme is considered to be expensive and not effective.

This paper adds two points to the literature. We focus on parameters that the government has under its control and address these parameters to the contribution decision itself. Corresponding to governmental goals, we check the effects of the subsidy both on the decision to contribute or not (extensive margin) and on the decision of how much to contribute (intensive margin).

First, we think that, from a governmental perspective, shifts of savings toward the Riester Scheme matter. Contributed money is fixed within the Riester contract up to the age of 62 and has to be paid out on a monthly basis until the end of life. Moreover, the pension cannot be transferred from one generation to another or lent by one individual to another. As a result, we think that the substitution rate shows how expensive it is for the government to shift "free" private savings to savings where the rules are controlled by the government. The elasticity of the decision on the extensive margin with respect to the price after taxes shows how effective the governmental action is.

Therefore, we focus on the effective size of the subsidy on the saving decision. That is why we have to separate effects from social characteristics such as the number of children or income and the impact of the subsidy itself. With our tax data, we can investigate the full range of the subsidy covering the more favorable tax option. Using a comprehensive tax calculator [11] we are able to analyze whether the probability to contribute is related to the subsidy itself or to other factors correlated with income or the number of children. Separating the underlying effects should lead to a meaningful evaluation of the effects of the legislated tax-based incentives. We use the variation in the tax price of the first euro contributed over time to identify the impact of the subsidy on the decision of whether or not to contribute (extensive margin). 
Second, we investigate to what extent the government meets its goal of implementing Riester savings of a legislatively predefined amount of the gross wage. To our knowledge, we are the first who analyze the contributed amount with respect to the price after taxes of the last euro contributed. We use the evolution of the maximum subsidized amount over time to show the impact of the subsidy on the decision regarding how much to contribute (intensive margin). Therefore, we show graphical evidence of contribution behavior on the price kink around the maximum subsidized amount.

The paper is structured mainly in two parts. The first part offers a brief description of the evolution of the Riester Scheme and the tax environment, followed by our analysis of the decision on the extensive margin. We show the marginal tax price of a Riester contribution, illustrate with descriptive statistics, discuss the identification, and show our main results followed by some robustness checks. The second part shows our analysis of the decision on the intensive margin. Based on a short description of the last euro tax price and its price kink, the corresponding data are described and graphical evidence on the contribution behavior with respect to the price kink is shown.

\section{Evolution of the Riester Scheme and the Tax Environment}

Here we give just a brief description of the legislated Riester Scheme; for a detailed overview see Börsch-Supan and Wilke [12]. The subsidy can be either a tax-free subsidy or a tax refund caused by a tax deduction. While the subsidy is based on a basic subsidy and a subsidy for each child, the value of the tax deduction is higher for higher incomes due to the progressive tax scale. The favorable type is chosen year-by-year via the tax assessment progress by the tax authorities. Although the subsidy is generous, the maximum eligible amount is fixed to a small level.

The tax-free subsidy is granted if an eligible person contributes to a Riester Pension (basic subsidy). Parents receive an additional subsidy for each child (child subsidy). An individual receives the full amount of subsidy if the savings are at least equal to a fixed percentage of the gross wage in the previous year (savings rate). Savings in this context mean the total saved amount, which is calculated based on the individual's own contributions plus the subsidy. The maximum eligible amount is fixed. If the person contributes more than that amount, there is no additional subsidy. To receive the full subsidy, the own contributions have to be at least equal to a legislated fixed amount (minimum savings).

From 2002 to 2008, there was an implementation phase. The evolution of the Riester components over time is displayed in Table 1. The 2002 amounts were doubled by 2004 , tripled by 2006 , and quadrupled by 2008 . Because all values increased stepwise every two years from 2002 to 2008 , they are also known as "Riester Stairs".

Tax deductions are alternatively granted if they are advantageous. Tax authorities check whether the deduction of the savings from the tax base (and the subsequent tax savings) or the tax-free subsidy is more favorable and, in every year, the more favorable approach is used. As a result, the applied tax scale of the subsequent year plays a crucial role here. That is why we take a closer look at the evolution of the tax scale from 2002 to 2008 . 
Table 1. Evolution of the riester components from 2002 to 2008.

\begin{tabular}{cccccc}
\hline Year & $2002 / 2003$ & 2004 & 2005 & $2006 / 2007$ & from 2008 \\
\hline Basic subsidy & $38 €$ & $76 €$ & $76 €$ & $114 €$ & $154 €$ \\
Child subsidy (born after 31.12.2007) & $46 €$ & $92 €$ & $92 €$ & $138 €$ & $185 €(300 €)$ \\
Savings rate & $1 \%$ & $2 \%$ & $2 \%$ & $3 \%$ & $4 \%$ \\
Maximum eligible amount & $525 €$ & $1,050 €$ & $1,050 €$ & $1,575 €$ & $2,100 €$ \\
Minimum savings & & & & & \\
& $38 €(1$ child $)$ & & & \\
& $30 €(>2$ children $)$ & & & \\
\end{tabular}

In Germany, taxable income is taxed by a direct progressive tax scale. Following a basic tax-free amount, the marginal tax rate is increasing linearly to the top tax rate. In contrast to other countries, the tax law is not indexed, resulting in "cold progression" every year. From 2002 to 2008 there have been major changes in the tax scale resulting from tax reform. We use a slight modification of the tax rate here: net-of-tax rate (ntr), which is calculated as one minus the marginal tax rate $(n t r=1-m t r)$. The $n t r$ can be interpreted as the price after taxes for tax-preferred goods. In Figure 1, the ntr is displayed for different taxable incomes. As we see, the lowest $n t r$ has increased from 0.52 in 2002 to over 0.55 in 2004 to 0.58 in 2005 while it has decreased for taxpayers with income above $250,000 €$ from 2007 to 0.55 .

\section{Extensive Margin}

\subsection{Tax Price}

In the analysis of the incentives, we need a relative measure of the subsidy. At a glance, it seems to be obvious to use the subsidy quota $(S Q)$ established by the German Statistical Office [13] [14]. The $S Q$ represents the governmental share (subsidy or taxes saved due to tax deduction) of the total saved amount.

$$
S Q=\frac{\max (\text { subsidy, taxes saved })}{\text { saved amount }}
$$

However, what we need for a meaningful interpretation with respect to individual preferences is the governmentally induced change in prices. That is why we transform the widely used $S Q$ to an after-tax price $(T P)$ :

$$
T P=1-S Q=1-\frac{\max (\text { subsidy, taxes saved })}{\text { saved amount }}
$$

Corresponding to the subsidy components of the Riester Scheme, the tax price is affected mainly by taxable income and the number of children. The tax price in 2002 for different income levels for a taxpayer with up to three children is illustrated in Figure 2. As we can see, the basic structure of the tax price can be divided into two parts. On the left tail, ranging from a constant up to the maximum tax price, the subsidy is more favorable. On the right tail, the tax deduction is more favorable. More children lead to lower tax prices for lower incomes. 


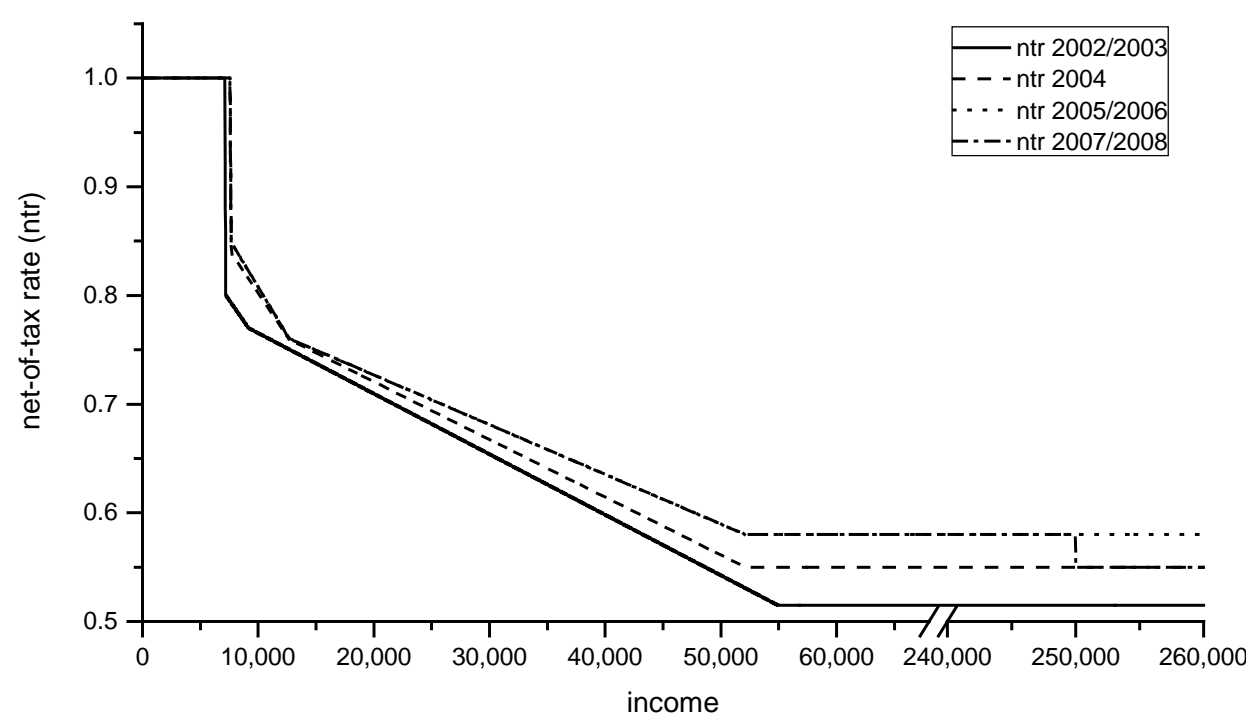

Figure 1. Evolution of the net-of-tax rate (ntr) over time. Source: Own calculations.

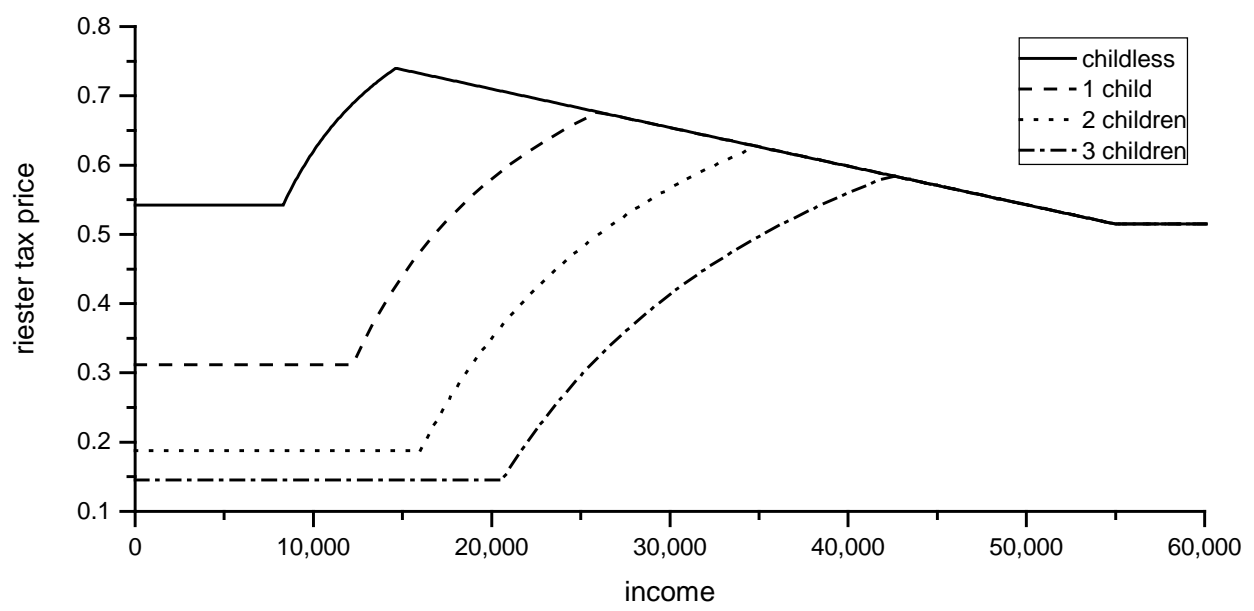

Figure 2. Tax price for different incomes and different numbers of children for the year 2002 . Source: authors' calculations.

On the left tail, are a flat part and a growing part. In the first part, the tax price is on a constant level, because the taxpayers' own contributions are constant. ${ }^{1}$ In the second part, the tax price is increasing. Although the subsidy remains constant, the taxpayers' own contributions are increasing as their income increases. Consequently, increasing income leads to a higher tax price. However, increasing income also results in higher tax rates. Thus, tax deductions become more favorable. On the right tail, the tax deduction is more favorable than the subsidy. Following the progressive tax scale, the tax price is decreasing as taxable income is growing, resulting in a flat zone. Although this basic structure remains the same, an increase in the number of children leads to higher subsidies and therefore shifts the left tail to the bottom right.

${ }^{1}$ For example, a contribution of minimum savings (45€) results in full subsidy (38€), resulting in a tax price of $1-(38 € /(45 €+38 €))=0.54$. 
Most important for us is the change in the tax environment over time. The Riester components vary over 2-year intervals ("Riester Stairs") in the implementation phase, resulting in a decrease in tax price for low incomes. While for middle incomes the tax price remains constant, it is increasing for higher incomes due to tax cuts.

Because the tax scale and tax base are not indexed, middle-income taxpayers face an increase in tax price over time. Moreover, for the same income, taxpayers with different numbers of children face different changes in the tax price (Figure 3). Consequently, taxpayers with different incomes and different numbers of children face different changes in the tax price.

\subsection{Data}

For this study, we use data from the German Taxpayer-Panel [15] [16], a balanced panel providing individual tax return data from German taxpayers. We use a $0.5 \%$ stratified random sample spanning eight years from 2001 to 2008. The tax price and the income after taxes are calculated using a comprehensive tax calculator [11].

In our dataset, we followed 80,394 taxpayers over eight years, resulting in 643,152 observations. Because the Riester Scheme was introduced in 2002, we dropped the 2001 wave, which left 562,758 observations. To ensure that only taxpayers eligible to contribute were in our dataset, we kept only wage earners (wage $>0$ ), which dropped 150,892 observations. As a result, our dataset consisted of seven years with 58,838 taxpayers eligible to contribute, resulting in 411,866 observations.

After these initial cuts, we dropped three groups of taxpayers as we are not sure if they constituted a plausible comparison group for the identification of the tax price effect. ${ }^{2}$ First, we considered that the taxpayers in our dataset with low incomes were not a plausible comparison group in particular because of the balanced structure of our tax

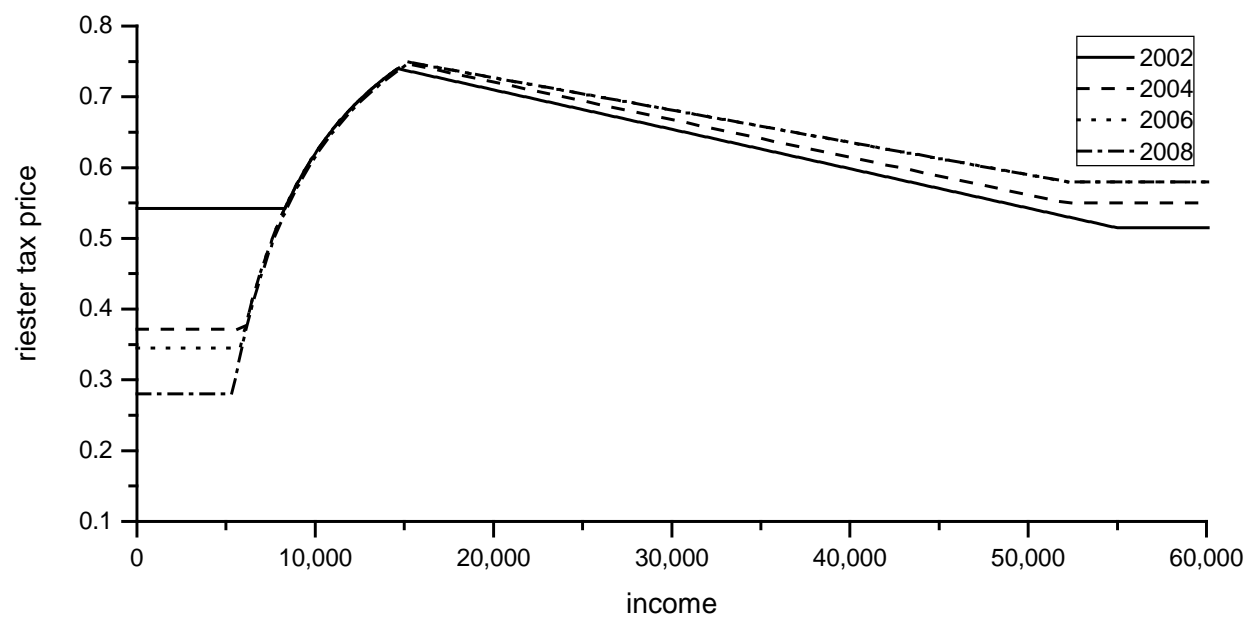

Figure 3. Variation of the Riester tax price for different incomes (childless) over time. Source: authors' calculations.

${ }^{2}$ In our robustness checks in Chapter 3.4.2, we checked to what extend our results were driven by these data cuts. 
data. ${ }^{3}$ Consequently we dropped 2023 taxpayers (14,161 observations) with a sum of income less than $10,000 €$. Second, we implemented a drop based on age. While taxpayers younger than 25 often are beginning their working life, those older than 55 often are close to their retirement. To keep only taxpayers in their main work phase, we kept only taxpayers between 25 and 55, thereby dropping an additional 10,738 taxpayers (75,166 observations). Third, we dropped an additional 4,756 taxpayers (33,292 observations) with a change in filing status (single or joint assessment) to be sure to compare the identical number of persons counted as one taxpayer over time. ${ }^{4}$ This led to our final dataset of 41,321 taxpayers over seven years (289,247 observations) (Table 2).

In Table 3, the sample statistics of the variables used in the regression are displayed. Our main variables of interest were calculated using a comprehensive tax calculator. The marginal tax price for the contribution was calculated using taxpayer information from the subsequent year (tax law, wage, number of children) and assuming that the taxpayer contributed the amount that was necessary to get the full subsidy ${ }^{5}$, the subsidy and the saved amount were calculated. Afterwards, the tax calculator checked whether the tax deduction of the saved amount or the subsidy was more favorable. Last, the more favorable amount was divided by the saved amount, resulting in the subsidy quota. One minus the subsidy quota is the tax price for this taxpayer. Income after taxes was calculated as ordinary taxable income without child allowance and Riester deduction less taxes.

Table 2. Data cuts.

\begin{tabular}{ccc}
\hline Label & Observations & Taxpayers \\
\hline Taxpayer-panel 2001-2008 & 643,152 & 80,394 \\
Wave 2001 & 80,394 & 0 \\
Non-eligible taxpayer & 150,892 & 21,556 \\
Resulting dataset & 411,866 & 58,838 \\
Income in 2002 <10,000€ & 14,161 & 2,023 \\
Age $<$ 25 or age $>$ 55 & 75,166 & 10,738 \\
Change in filing status & 33,292 & 4,756 \\
Final dataset & 289,247 & 41,321 \\
\hline
\end{tabular}

Source: Research Data Centers of the Federal Statistical Office and the Statistical Offices of the Länder, German Taxpayer-Panel, 2001-2008, authors' calculations.

${ }^{3}$ Part of this problem is called mean reversion in the context of tax price regressions with income growth as a dependent variable [17]. The main idea is that on the left tail of the income distribution there is exogenous positive income growth. Because taxpayers without income do not have to file a tax return, they are not covered in the cross-sectional tax data. Consequently, in the balanced dataset, taxpayers with low income and decreasing income over time are more likely to be not included in the sample than those with increasing incomes.

${ }^{4}$ Married couples are typically assessed jointly and therefore one taxpayer while single assessed taxpayers are only one person.

${ }^{5}$ This increment is not as important as it seems. According the Riester rule itself the tax price for the first and the last subsidized euro is just the same. However, rounding rules within the tax assessment process generates discontinuous results for small numbers. Moreover, for taxpayers with low income only small amounts like $30 €$ to $60 €$ are subsidized which can cause some problems using a fixed increment like $100 €$. 
Table 3. Sample statistics.

\begin{tabular}{cccccccc}
\hline Label & Mean & s.d. & p5 & p25 & p50 & p75 & p95 \\
\hline Riester-dummy (C) & 0.1546 & 0.3615 & 0 & 0 & 0 & 0 & 1 \\
Tax price (TP) & 0.5144 & 0.1882 & 0.1333 & 0.4461 & 0.5647 & 0.6516 & 0.7306 \\
$\ln$ (TP) & -0.7722 & 0.5426 & -2.0149 & -0.8048 & -0.5715 & -0.4279 & -0.3133 \\
TP-instrument & 0.5134 & 0.1872 & 0.1333 & 0.4461 & 0.5654 & 0.6503 & 0.7251 \\
$\ln$ (TP-instrument) & -0.7758 & 0.5460 & -2.0149 & -0.8071 & -0.5703 & -0.4299 & -0.3209 \\
Income & 72,372 & 272,938 & 14,380 & 30,400 & 47,879 & 88,431 & 185,548 \\
$\ln$ (income) & 10.7828 & 1.1419 & 9.5736 & 10.3222 & 10.7764 & 11.3900 & 12.1311 \\
Income-instrument & 67,102 & 101,221 & 15,158 & 30,733 & 47,978 & 82,663 & 160,939 \\
$\ln$ (income-instrument) & 10.7680 & 1.3015 & 9.6263 & 10.3331 & 10.7785 & 11.3225 & 11.9888 \\
Dummy: children $=1$ & 0.2385 & 0.4262 & 0 & 0 & 0 & 0 & 1 \\
Dummy: children $=2$ & 0.2987 & 0.4577 & 0 & 0 & 0 & 1 & 1 \\
Dummy: children > 2 & 0.1047 & 0.3061 & 0 & 0 & 0 & 0 & 1 \\
Age & 2,165 & 677 & 1,089 & 1,600 & 2,116 & 2,704 & 3,249 \\
$\ln$ (renting and leasing) & 3.0640 & 4.1479 & 0 & 0 & 0 & 8 & 10 \\
(dividends and interests) & 1.8569 & 3.5271 & 0 & 0 & 0 & 0 & 12,293 \\
Observations & 289,247 & & & & & \\
\hline
\end{tabular}

Source: Research Data Centers of the Federal Statistical Office and the Statistical Offices of the Länder, German Taxpayer-Panel, 2001-2008, authors' calculations.

Many of the other variables used in regression can be taken immediately from our tax data. The dummy for the decision to contribute to a Riester Pension is $C=1$ if the taxpayer contributed to a Riester Pension and $C=0$ otherwise. The number of children was equal to the number of dependent children who were covered on the tax return of their parents. This variable was used to generate dummy variables for having one child, two children, or more than two children. Age and $\mathrm{Age}^{2}$ were generated using the date of birth of the taxpayer and the subsequent year. If the taxpayer was jointly assessed, the age of Person A (typically the person who declares more money) was used. Finally, income from renting and leasing and income from dividends and interest entered the regression in logged form.

In Figure 4, the evolution of the tax price instrument over time is shown (see Chapter 3). In the upper panel, we show the price both for taxpayers receiving the subsidy and for taxpayers where tax deductions are more favorable. From 2002 to 2004 it is obvious that while the price was increasing for those receiving tax deductions due to tax cuts, it was decreasing slightly for those receiving the subsidy due to higher subsidies. In 2005 the price for those receiving the subsidy was growing more strongly than for those receiving tax deductions. From 2005 on, both lines mainly follow the same slightly decreasing trend due to growing gross/taxable income and fixed term tax law. 


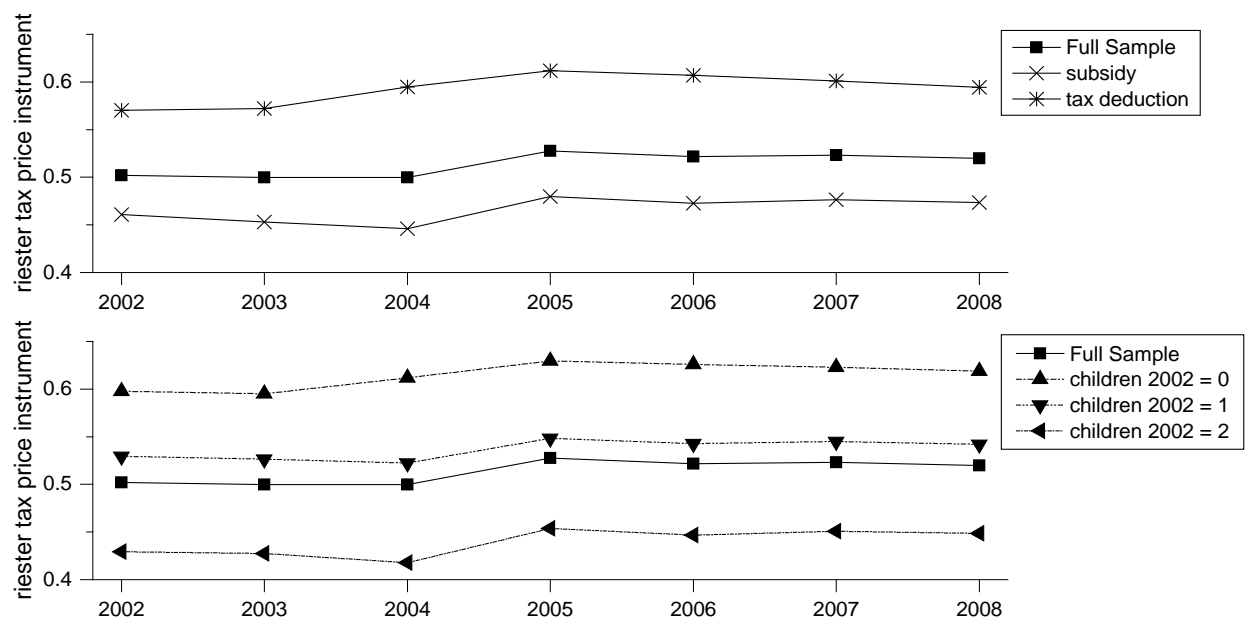

Figure 4. Evolution of Riester tax price instrument over time. Source: Research Data Centers of the Federal Statistical Office and the Statistical Offices of the Länder, German Taxpayer-Panel, 2001-2008, authors' calculations.

In the bottom part, the evolution of the price for different numbers of children is displayed. Following our calculations above, a greater number of dependent children yielded a lower tax price. Again, over time we show different evolutions before 2004 and mainly the same shape from 2005 on with one exception: from 2004 to 2005, the price increased more sharply for taxpayers with more dependent children.

\subsection{Identification}

We followed Heim and Lurie [18] and thought of the contribution decision $C_{i t}$ (where $C_{i t}=1$ if the taxpayer $i$ contributed to a Riester Pension in year $t$ and $C_{i t}=0$ otherwise) in a parsimonious model as a function of the first euro price of the contribution $T P_{i p}$ the income after taxes Income $i$ and some control variables $X_{i t}$. Included in $X_{i t}$ are other factors that were assumed to be associated with the individual contribution decision and that varied over time. We controlled for the number of children, age, and income from renting and leasing and income from dividends and interests.

$$
C_{i t}=\beta_{1} \ln \left(T P_{i t}\right)+\beta_{2} \ln \left(\text { Income }_{i t}\right)+\beta_{3} X_{i t}+v_{i}+\gamma_{t}+\varepsilon_{i t}
$$

The tax price effect was our main parameter of interest. The marginal tax price was calculated as described above. Because we assumed the Riester Pension to be a normal good, we expected that rising prices resulted in a lower propensity to contribute and therefore they were considered a negative sign. So, the effective size of the tax price shows how much control the government has regarding the individual retirement decision by setting the tax price via subsidizing.

The effect of income was covered because standard microeconomic theory predicts not only substitution effects but also income effects of tax changes. The after-tax income was calculated as described above. Conventional wisdom about the effect of taxes on normal goods let us assume that-ignoring substitution effects-increasing income shifted the budget constraint in a way that more goods could be consumed than before. So, a higher income should result in a higher probability to contribute to a Riester 
Pension. Therefore, we expected this to be a positive sign [19].

Because of the generous child subsidy, taxpayers with (more) children received a larger overall subsidy under the Riester contract. The number of children was found to play a dominating role in the Riester decision process. A higher number of children were found to be associated with a higher Riester propensity [7] [20]. Since we covered the price effect arising from children in our tax price model as shown above, our child effect should only cover non-price-related factors. We expected that having children lowered the annual savings on average and decreased the importance of savings for old age provisions [21]. Thus, we expected this to be a negative sign.

We covered age as a proxy for the time between contribution and payout of the pension. Because of the long-term character of the Riester Scheme, we expected older taxpayers to have a lower propensity and therefore to be a negative sign.

We also controlled for other old age provision channels. However, in our tax data, we did not have broad information about this. So we solely included income from dividends and interest (which was in fact poorly covered) and income from renting and leasing (which was well covered but poorly measured). There were at least two economic effects covered by these variables. On the one hand, these income sources were substitutes to Riester, so we expected them to be a negative sign. On the other hand, financial knowledge also was found to be an important factor in the Riester puzzle [20] [22]. As these income sources could also be interpreted as a proxy for financial knowledge, a positive sign also seemed plausible.

But there were other factors that could have affected contribution decisions, but were omitted in our dataset. Several individual effects were correlated both with contribution propensity and with our tax price variable. We could not control for these variables as they were not included in our dataset. This would have resulted in biased estimates. For example, suppose that taxpayers with a higher saving propensity were likely to have a higher contribution propensity and have higher income and therefore a higher tax rate resulting in lower tax prices. An estimation without covering these individual effects would have led to a biased estimate of the tax price. Because several individual saving-related characteristics were not included in our dataset, between-variation characteristics were clearly ruled out for identification issues. Consequently, we exclusively used within-variation by controlling for individual fixed effects $v_{i}$.

Moreover, we included time-fixed effects to cover effects that were correlated with the subsequent year and that had an impact on the contribution decision. The subprime crisis started in 2007. This could have decreased the overall saving propensity and, therefore, have affected the Riester contribution decision. If the tax price decreased in these years, the effect of the tax price would be underestimated. To deal with such issues, we included a dummy for each year after 2002, covering time-fixed effects $y_{t}$.

Using variations of the tax price to identify price effects revealed another issue. The tax price of the Riester Scheme is a non-linear function of actual income (see Figure 1). If there were a positive exogenous income shock, the tax price of taxpayers with different incomes either decreased or increased in a non-linear fashion. This is why the use 
of the tax price as an independent variable might have led to a biased estimate [23]. To handle this issue, the tax price was instrumented by a synthetic tax price [19]. To build the synthetic tax price, individual taxpayer information from a start year was used to generate synthetic tax prices of the actual year. Following others, the taxable income was updated by the mean growth of taxable income in the dataset [24]. The tax scale of the actual year was applied to the updated income. This procedure ensured that the overall income trend and the changes in the tax law were the only sources of variation in the synthetic tax price. ${ }^{6}$

For our income effects, we also used only law-induced changes. This is important in the event that non-law-induced changes in income (e.g., job effects) had another impact on contribution behaviors than did law-induced income changes. We concentrated on law-induced changes because we were interested mainly in the effect of governmental action on contribution behaviors. So, for after-tax income, we applied the same instrument strategy [19]. Synthetic income after taxes was used as an instrument for income after taxes. Therefore, the income of our first year (2002) was updated by the mean growth of income in the dataset to synthetic current year income. Using the tax calculator, synthetic taxes of the current year were based on actual tax law and synthetic income was calculated. Lastly, synthetic income after taxes was calculated as synthetic income of the current year less synthetic taxes of the current year.

Because of the limited dependent variable, the model prediction of the OLS model is flawed. The standard textbook approach is to use non-linear models such as probit or logit transformation [25] [26]. However, as we described above, we had to handle two more issues: endogeneity and unobserved effects. Therefore, we had to include individual fixed effects and use an instrumental approach. We were not able to find an estimation technique covering all three issues. Thus, we used a technique that was close to our question. As we have stated above, we were not interested primarily in a prediction of the contribution rate, but were interested mostly in the marginal effects of the tax price that relied mainly on the exogeneity of the tax price and covered unobserved effects over time. That is why we used the linear probability model (LPM) that works well when applied for average marginal effects [27] [28].

\subsection{Results}

\subsubsection{Main Results}

In Table 4, the regression results of the LPM for the decision on extensive margins are displayed. There were five specifications that were different with respect to the model and the variables used. While specification (I) was estimated using OLS, in specifications (II) to (V) an instrumental variable approach was employed.

In columns (I) and (II), we regressed our tax-related variables exclusively on the contribution decision. In specification (I), both the tax price and income after taxes were not instrumented. This results in statistically significant estimates but economically ${ }^{6}$ Using this procedure, we also did not use any tax price variation resulting from changes in the number of dependent children of the taxpayer. At first, this was simply a result of the solution for the measurement error described above. Second, changes in the tax price due to changes in the number of children itself would also lead to biased estimates because of the non-linear tax price effects. 
Table 4. Extensive margin estimation results of LPM.

\begin{tabular}{|c|c|c|c|c|c|}
\hline & (I) & (II) & (III) & (IV) & $(\mathrm{V})$ \\
\hline \multicolumn{6}{|l|}{ Main variables } \\
\hline $\ln ($ tax price $)$ & $-0.0257^{\star * *}$ & $-0.1538^{\star * *}$ & $-0.1548^{\star * *}$ & $-0.1382^{\star * *}$ & $-0.1413^{\star * *}$ \\
\hline \multirow{3}{*}{$\ln ($ income $)$} & $(0.0015)$ & $(0.0143)$ & $(0.0145)$ & $(0.0144)$ & $(0.0145)$ \\
\hline & $0.0064^{* * *}$ & -0.0080 & -0.0083 & -0.0067 & -0.0058 \\
\hline & $(0.0007)$ & $(0.0191)$ & $(0.0192)$ & $(0.0190)$ & $(0.0189)$ \\
\hline \multicolumn{6}{|l|}{ Other variables } \\
\hline Number of children $=1$ & & & $\begin{array}{c}0.0106^{\star * *} \\
(0.0038)\end{array}$ & $\begin{array}{l}-0.0032 \\
(0.0039)\end{array}$ & $\begin{array}{l}-0.0042 \\
(0.0039)\end{array}$ \\
\hline Number of children $=2$ & & & $\begin{array}{c}0.0031 \\
(0.0079)\end{array}$ & $\begin{array}{c}-0.0195^{\star *} \\
(0.0079)\end{array}$ & $\begin{array}{c}-0.0216^{* * *} \\
(0.0080)\end{array}$ \\
\hline Number of children $>2$ & & & $\begin{array}{l}-0.0069 \\
(0.0119)\end{array}$ & $\begin{array}{c}-0.0372^{\star * *} \\
(0.0119)\end{array}$ & $\begin{array}{c}-0.0404^{* * *} \\
(0.0120)\end{array}$ \\
\hline $\mathrm{Age}^{2}$ & & & & $\begin{array}{c}-0.0005^{\star * *} \\
(0.0000)\end{array}$ & $\begin{array}{c}-0.0005^{\star * *} \\
(0.0000)\end{array}$ \\
\hline $\ln$ (renting and leasing) & & & & & $\begin{array}{l}0.0009^{\star *} \\
(0.0004)\end{array}$ \\
\hline $\ln$ (dividends and interests) & & & & & $\begin{array}{c}0.0028^{* * *} \\
(0.0005)\end{array}$ \\
\hline Instrumenting & No & Yes & Yes & Yes & Yes \\
\hline Individual fixed effects & Yes & Yes & Yes & Yes & Yes \\
\hline Year fixed effects & Yes & Yes & Yes & Yes & Yes \\
\hline Observations & 289,247 & 289,247 & 289,247 & 289,247 & 289,247 \\
\hline $\mathrm{R}^{2}$ & 0.1098 & 0.0823 & 0.0819 & 0.0931 & 0.0926 \\
\hline \multicolumn{6}{|l|}{ First stage results } \\
\hline \multicolumn{6}{|l|}{ Tax price } \\
\hline $\mathrm{R}^{2}$ & $(-)$ & 0.0235 & 0.0933 & 0.0936 & 0.0936 \\
\hline F-statistic & $(-)$ & 746.84 & $2,319.19$ & $2,132.65$ & $1,828.32$ \\
\hline \multicolumn{6}{|l|}{ Income } \\
\hline $\mathrm{R}^{2}$ & $(-)$ & 0.0164 & 0.0165 & 0.0179 & 0.0217 \\
\hline F-statistic & $(-)$ & 516.81 & 377.64 & 376.71 & 393.08 \\
\hline
\end{tabular}

Notes: Dependent variable is the contribution decision, which is 1 if the taxpayer contributes to a Riester Pension and 0 otherwise. Specification (I) was estimated using OLS. Specifications (II) to (V) were estimated using TSLS with instrumented tax price and income after taxes. Instruments were calculated as described in the main text. In the bottom part of this table, two goodness-of-fit measures of the corresponding first stage regression are shown. Asterisks denote significance at the $10 \%\left({ }^{*}\right), 5 \%\left(^{* *}\right)$, and $1 \%\left({ }^{* * *}\right)$ level. Source: Research Data Centers of the Federal Statistical Office and the Statistical Offices of the Länder, German Taxpayer-Panel, 2001-2008, authors' calculations.

irrelevant parameters, which maybe biased because of the potential endogeneity of the tax price. In specification (II), we addressed the potential endogeneity of the tax price by instrumenting both the tax price and the income after taxes using the synthetic tax price and synthetic income after taxes as described above. Goodness-of-fit statistics of 
the corresponding first stage regressions are shown in the bottom part of the table. As we show, both $\mathrm{R}^{2}$ and the F-statistic are large and therefore we do not think that the instrument suffered from the weak instrument issue. ${ }^{7}$ This approach yields to both a statistically significant and economically relevant parameter estimate of the tax price of -0.15 , while the income effect was small and insignificant.

In columns (III) to (V), several additional variables were added to serve as a proxy for other time-invariant effects that could possibly have affected the propensity to contribute. Prior findings about the Riester Scheme [8] [12] suggested that especially the number of children was driving the probability to contribute. As we argued in our identification strategy, the impact of the number of children on the tax price should be covered by the tax price leaving only the "pure" child effect on the child parameter. As we added dummies for the number of children in specification (III), we got only a small economically irrelevant effect of the children itself, indicating a successful identification of the tax price effect.

In columns (IV) and (V), we additionally added other control variables. In column (IV), age was added as a proxy for different contribution probabilities at different ages. Consistent with life cycle theory, older taxpayers had a lower propensity to contribute. In column (V), we also added retirement control variables to check if other potential saving decisions had an impact on the Riester decision. Controlling also for income from dividends and interests and real estate investments yielded only small positive effects of these other old age saving options. It seemed that the effect of financial knowledge was stronger than the substitution effect. However, the overall effect on the contribution decision was negligible.

Because the most comprehensive controls were applied in column $(\mathrm{V})$, this specification acted as our central specification. There we got a statistically significant estimate of the tax price of -0.14 on the decision to contribute to a Riester Pension. The results do not show an income effect. As in the other specifications, the number of children and age yielded very small negative effects. Consistent with Angrist and Pischke [27] and Wooldridge [28], we did not interpret the coefficient of -0.14 as an overall linear marginal effect, but calculated local marginal effects at the sample mean. In our sample, the mean tax price was increasing over time by slightly over 5.72\% ([0.5230/0.4947] -1$)$. With our coefficient of -0.14 , this would lead to a decrease in contribution rate of $0.8 \%$ points $(-0.14 \times 5.72 \%) .{ }^{8}$ In the context of the baseline contribution rate, we would suggest a $13.5 \%$ decrease in contribution rate (from $5.93 \%$ by $-0.8 \%$ to $5.13 \%$ ). So, the overall increase in tax price of $5.72 \%$ would lead to a decrease in contribution rate of $13.5 \%$, and thus let us calculate an implied elasticity of $-2.36(-13.5 \% / 5.72 \%)$.

However, these average effects mask the heterogeneity of the evolution of the tax ${ }^{7}$ As a rule of thumb, the F-statistic of the first stage has to be greater than 10 [29].

${ }^{8}$ The tax price and the income after taxes enter the regression in logged form. In that case, the estimated coefficients of these variables can easily be interpreted as semi-elasticities. As a result, the estimated coefficients reflect the percentage point change of the probability to contribute that would occur if the tax price or the income after taxes changes by one percent. For example, the tax price coefficient of -0.14 in our central specification indicated that the probability to contribute to a Riester Pension would decrease by $0.14 \%$ points if the tax price increases by $1 \%$. 
price in the sample. For example, taxpayers getting their first child in our sample yielded an average decrease in tax price of $14.23 \%$ ([0.5025/0.5859] - 1). Again, with our coefficient of -0.14 , this would lead to an increase in propensity of $1.99 \%$ points $(-0.14 \times-14.23 \%)$. In the context of the baseline contribution rate, we suggest a $43.36 \%$ increase in contribution rate (from $4.59 \%$ by $1.99 \%$ to $6.58 \%$ ). As a result, the overall decrease in tax price of $14.23 \%$ would lead to an increase in the contribution rate of $43.36 \%{ }^{9}$ The implied elasticity is $-3.05(43.36 \% /-14.23 \%)$.

Overall, it can be stated that the government has control over the average Riester contribution rate by setting the tax price. Moreover, the special subsidizing of parents via child subsidies led to a comprehensive shift in tax price for taxpayers getting children and consequently to a higher tax price induced contribution rate.

\subsubsection{Robustness Checks}

In Table 5, we checked the results of other regression models as a check of the robustness of the central estimates. For a comparison, we show the results of the central

Table 5. Extensive margin estimation results of LPM, robustness checks for different models.

\begin{tabular}{|c|c|c|c|c|c|}
\hline Main variables & LPM (I) & LPM (II) & Logit (III) & Probit (IV) & Probit (V) \\
\hline $\ln ($ tax price $)$ & $-0.1413^{* * *}$ & $-0.0155^{\star * *}$ & $-0.0932^{\star * *}$ & $-0.2254^{* * *}$ & $-0.1418^{\star * *}$ \\
\hline \multirow{3}{*}{$\ln$ (income) } & $(0.0145)$ & $(0.0015)$ & $(0.0353)$ & $(0.0095)$ & $(0.0057)$ \\
\hline & -0.0058 & $0.0050^{* * *}$ & $0.1344^{* * *}$ & $0.0127^{\star *}$ & $0.0141^{\star * *}$ \\
\hline & $(0.0189)$ & $(0.0007)$ & $(0.0233)$ & $(0.0060)$ & $(0.0030)$ \\
\hline \multicolumn{6}{|l|}{ Other variables } \\
\hline Number of children $=1$ & $\begin{array}{l}-0.0042 \\
(0.0039)\end{array}$ & $\begin{array}{c}0.0190^{\star * *} \\
(0.0026)\end{array}$ & $\begin{array}{c}0.4396^{\star * *} \\
(0.0808)\end{array}$ & $\begin{array}{c}0.1757^{\star * *} \\
(0.0085)\end{array}$ & $\begin{array}{c}0.1909^{\star * *} \\
(0.0083)\end{array}$ \\
\hline Number of children $=2$ & $\begin{array}{c}-0.0216^{* * *} \\
(0.0080)\end{array}$ & $\begin{array}{c}0.0396^{\star * *} \\
(0.0034)\end{array}$ & $\begin{array}{c}0.7564^{\star * *} \\
(0.1029)\end{array}$ & $\begin{array}{c}0.3018^{\star * *} \\
(0.0092)\end{array}$ & $\begin{array}{c}0.3421^{\star * *} \\
(0.0082)\end{array}$ \\
\hline Number of children $>2$ & $\begin{array}{c}-0.0404^{\star * *} \\
(0.0120)\end{array}$ & $\begin{array}{c}0.0528^{* * *} \\
(0.0051)\end{array}$ & $\begin{array}{c}1.0319^{\star * *} \\
(0.1459)\end{array}$ & $\begin{array}{c}0.3902^{* * *} \\
(0.0126)\end{array}$ & $\begin{array}{c}0.4508^{* * *} \\
(0.0110)\end{array}$ \\
\hline $\mathrm{Age}^{2}$ & $\begin{array}{c}-0.0005^{* * *} \\
(0.0000)\end{array}$ & $\begin{array}{c}-0.0006^{* * *} \\
(0.0000)\end{array}$ & $\begin{array}{c}0.0004 \\
(0.0006)\end{array}$ & $\begin{array}{c}-0.0002^{* * *} \\
(0.0000)\end{array}$ & $\begin{array}{c}-0.0002^{* * *} \\
(0.0000)\end{array}$ \\
\hline $\ln$ (renting and leasing) & $\begin{array}{l}0.0009^{* *} \\
(0.0004)\end{array}$ & $\begin{array}{l}0.0008^{* *} \\
(0.0004)\end{array}$ & $\begin{array}{l}0.0232^{\star *} \\
(0.0107)\end{array}$ & $\begin{array}{c}-0.0116^{* * *} \\
(0.0008)\end{array}$ & $\begin{array}{c}-0.0110^{* * *} \\
(0.0008)\end{array}$ \\
\hline $\ln$ (dividends and interests) & $\begin{array}{c}0.0028^{* * *} \\
(0.0005)\end{array}$ & $\begin{array}{c}0.0025^{\star * *} \\
(0.0002)\end{array}$ & $\begin{array}{c}0.0536^{\star * *} \\
(0.0071)\end{array}$ & $\begin{array}{c}-0.0058^{\star * *} \\
(0.0010)\end{array}$ & $\begin{array}{c}-0.0056^{\star * *} \\
(0.0009)\end{array}$ \\
\hline Instrumenting & Yes & No & No & Yes & No \\
\hline Individual fixed effects & Yes & Yes & Yes & No & No \\
\hline Year fixed effects & Yes & Yes & Yes & Yes & Yes \\
\hline Observations & 289,247 & 289,247 & 75,586 & 289,247 & 289,247 \\
\hline
\end{tabular}

Notes: Dependent variable is the contribution decision, which is 1 if the taxpayer contributed to a Riester Pension and 0 otherwise. Specification (I) was estimated using TSLS with instrumented tax price and income after taxes. Instruments were calculated as described in the main text. Specification (II) was estimated using OLS. Specifications (III) to $(\mathrm{V})$ were estimated using binary response models. Asterisks denote significance at the $10 \%\left({ }^{*}\right), 5 \%(* *)$, and $\left.1 \%{ }^{* * *}\right)$ level. Source: Research Data Centers of the Federal Statistical Office and the Statistical Offices of the Länder, German Taxpayer-Panel, 2001-2008, authors' calculations.

${ }^{9}$ We do not cover marginal "pure" child effects of the first child to calculate marginal child effects because we could not show that these effects are different from zero, at least at the $10 \%$ significance level. 
specification in column (I). If we had not instrumented for tax price and income after taxes and consequently had run a simple OLS, we would have estimated effects of our tax variable that were not economically relevant. On the other hand, children had a significant positive influence on the contribution decision. As we argued, in this specification, we could not be sure to capture tax effects correctly because of the possible endogeneity of the tax price. So, we think that the positive child effects were not causal marginal child effects economically but instead were not precisely estimated tax price effects.

In specifications (III) to (V), we used classical binary response models. As we have argued, we could not employ a solution for all issues of our identification problem (both instrumenting for tax price and fixed effects estimation). Moreover, we could not interpret the coefficients in a simple manner [30], as these were non-linear models resulting in non-linear marginal effects. ${ }^{10}$ Nonetheless, the corresponding tax price coefficients had the same sign and were not extremely large or small.

In Table 6, we check whether our data cuts had an impact on our main findings. We presented the regression results of our preferred specification using all combination of our three data cuts. In column (I) of Table 6, our main results using full data cuts are displayed. In columns (II) to (IV), the results using only two data cuts are displayed. In columns (V) to (VII), the results using only one data cut are displayed. In the last column (column VIII), no data cut is used. Keeping only taxpayers between 25 and 55 in 2002 had the greatest effect on the tax price estimate. Comparing the tax price coefficients over these specifications shows that the estimate varies between -0.09 and -0.14 . Overall, it can be stated that, although we used different data cuts, our central estimates were still in line with theory and within an acceptable range.

\section{Intensive Margin}

\subsection{Tax Price Kink}

As we have seen, the government has control over the decision to contribute, at least to some extent. However, the governmental goal is not only to save one euro but also to overcome the financing gap due to reduced returns of pay-as-you-go pensions. The main idea is that employees should save a legislatively predefined amount. This amount has increased stepwise from 2002 to 2008. In this Chapter, we used the stepwise increase in the maximum eligible amount in the implementation phase to analyze the relationship between the contributed amount and the tax price of the last euro contributed.

To analyze behavior on an intensive margin, we needed a variation of the tax price with respect to the contributed amount. However, for taxpayers who received the subsidy (tax deduction), there was no tax price variation for subsidized contributions (only

${ }^{10}$ To be precise, in fact we were able to calculate some odds ratios. But due to non-linearity, odds ratios could not be transformed to linear individual marginal effects. The main issue was that marginal effects depend on $v_{i}$, which were not computed (incidental parameters problem). So, we were able to calculate only marginal effects assuming fixed effects to be zero, which seems not to be a realistic assumption. 
Table 6. Extensive margin estimation results of LPM, robustness checks for different data cuts.

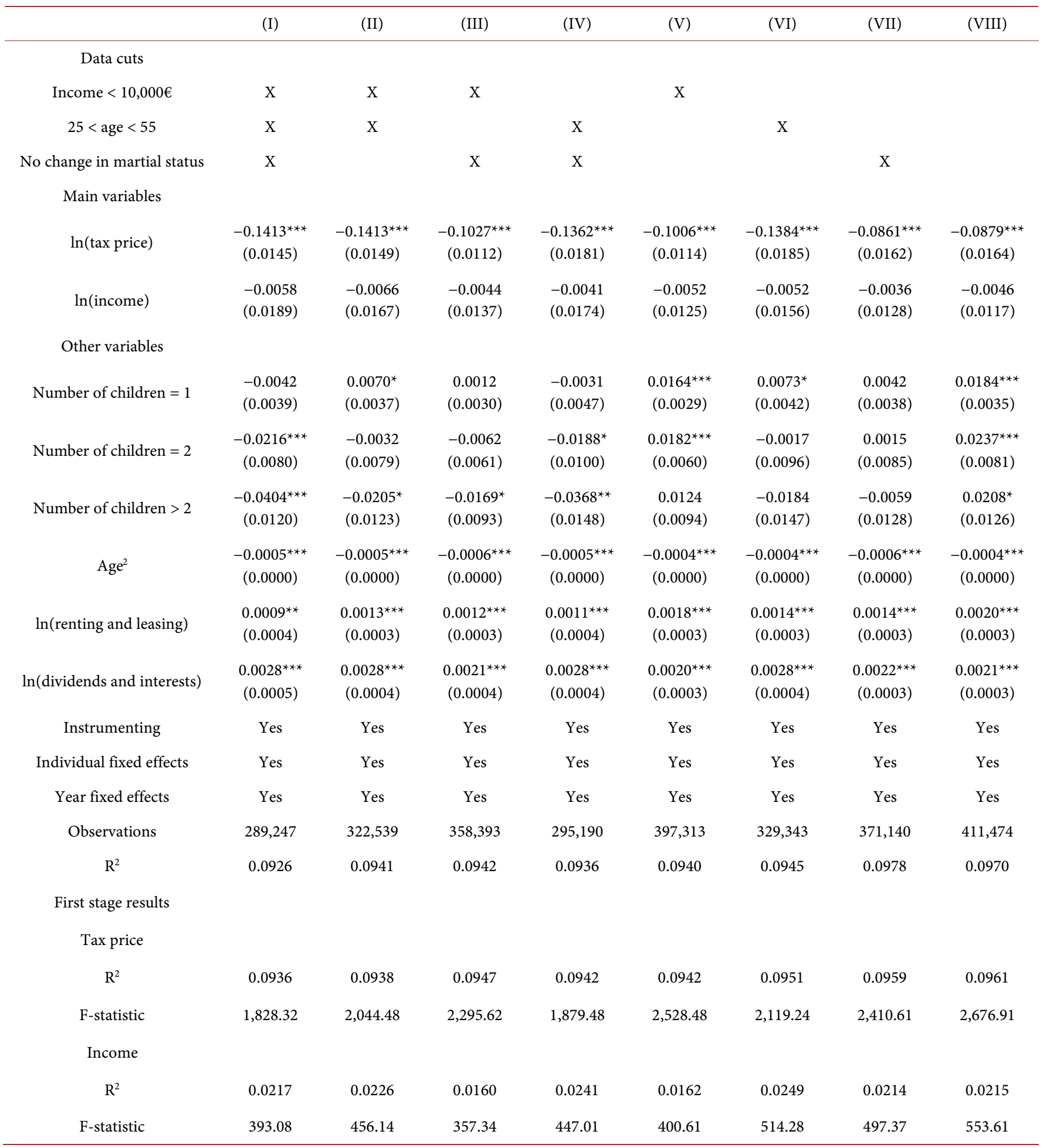

Notes: Dependent variable is the contribution decision, which is 1 if the taxpayer contributes to a Riester Pension and 0 otherwise. All specifications were estimated using TSLS with instrumented tax price and income after taxes. Instruments were calculated as described in the main text. Specification (I) was our main specification. Specifications (II) to (VIII) differ with respect to the data cuts used, which are displayed at the top of the table. Asterisks denote significance at the $10 \%\left({ }^{*}\right), 5 \%\left({ }^{*}\right)$, and $1 \%\left(^{* * *}\right)$ level. Source: Research Data Centers of the Federal Statistical Office and the Statistical Offices of the Länder, German Taxpayer-Panel, 2001-2008, authors' calculations. 
a small tax progression). ${ }^{11}$ But for all taxpayers, the tax price for contributions exceeding the maximum eligible amount switched to 1 . Therefore, we focused on the tax price kink point generated by the Riester Scheme. Ignoring tax progression, the last euro tax price $T P^{\text {ast }}$ can be expressed as a step function of the contributed amount $C$ and switches after the maximum eligible amount $X$ :

$$
T P^{\text {last }}= \begin{cases}T P, & \text { if } C \leq X \\ 1, & \text { if } C>X\end{cases}
$$

This kink (Figure 5) was appropriate to evaluate tax-induced behavior because of different features. The change in tax price around the kink was large and consequently salient, so taxpayers had a strong incentive to react [31] [32]. Money also could be shifted easily between tax-preferred and non-tax-preferred investments in contrast to other tax-related decisions (e.g., hours of work). In addition, the maximum subsidized contributions are small, so it should be easy for every taxpayer to reach them.

The location of the tax price kink was determined by individual factors (income, number of children) and institutional factors (savings rate, minimum savings, maximum savings, tax scale; see Table 1 in Chapter 2).

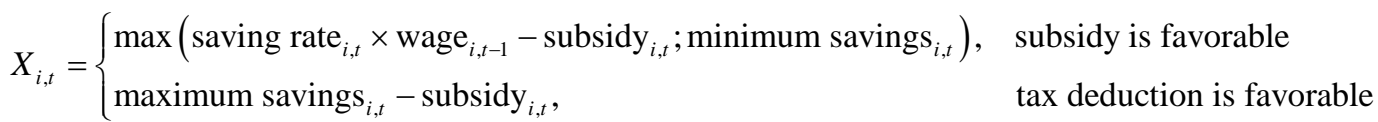

The Riester Scheme generated different tax price kinks within one year for different taxpayers with different incomes or different numbers of children. For example, a taxpayer in year 2002 without dependent children (continuous line in Figure 6) and an income of $30,000 €$ could contribute from $1 €$ to $487 €(525 €-38 €)$ for a tax price of $T P<1$ (which is here $1-0.485 \times 1.055=0.4883$ ). For any contributions exceeding $487 €$, the last euro tax price is 1.

Moreover, even for a taxpayer with identical individual factors, the location of the kink $X$ differed over time because of changes in the Riester Scheme (see Figure 7). In our example, in 2002, a taxpayer with an income of 30,000€ and no dependent children could contribute from $1 €$ to $487 €(525 €-38 €)$ for a tax price of $T P<1$. In 2003 , the maximum subsidized amount was also $487 €$. In 2004, the subsidized contribution

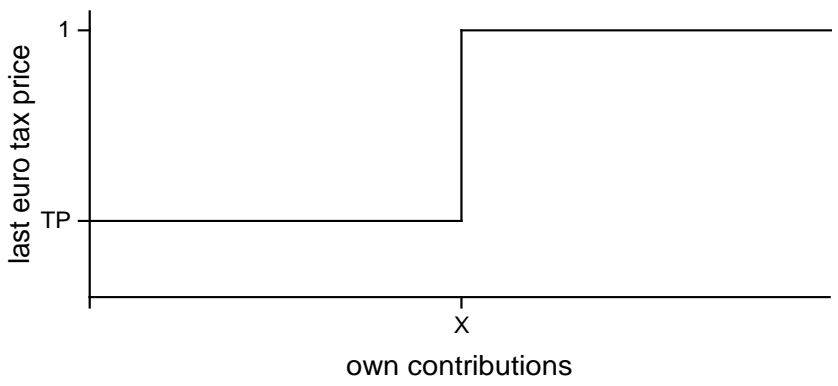

Figure 5. Kink in tax price for the last euro contributed.

\footnotetext{
${ }^{11}$ However, the maximum eligible amount (see Chapter 2) was limited to a fairly small level. In relation to the variation generated by the kink, progression effects seemed not to be the dominating factor. That is why we focused on kinks rather than progression effects.
} 


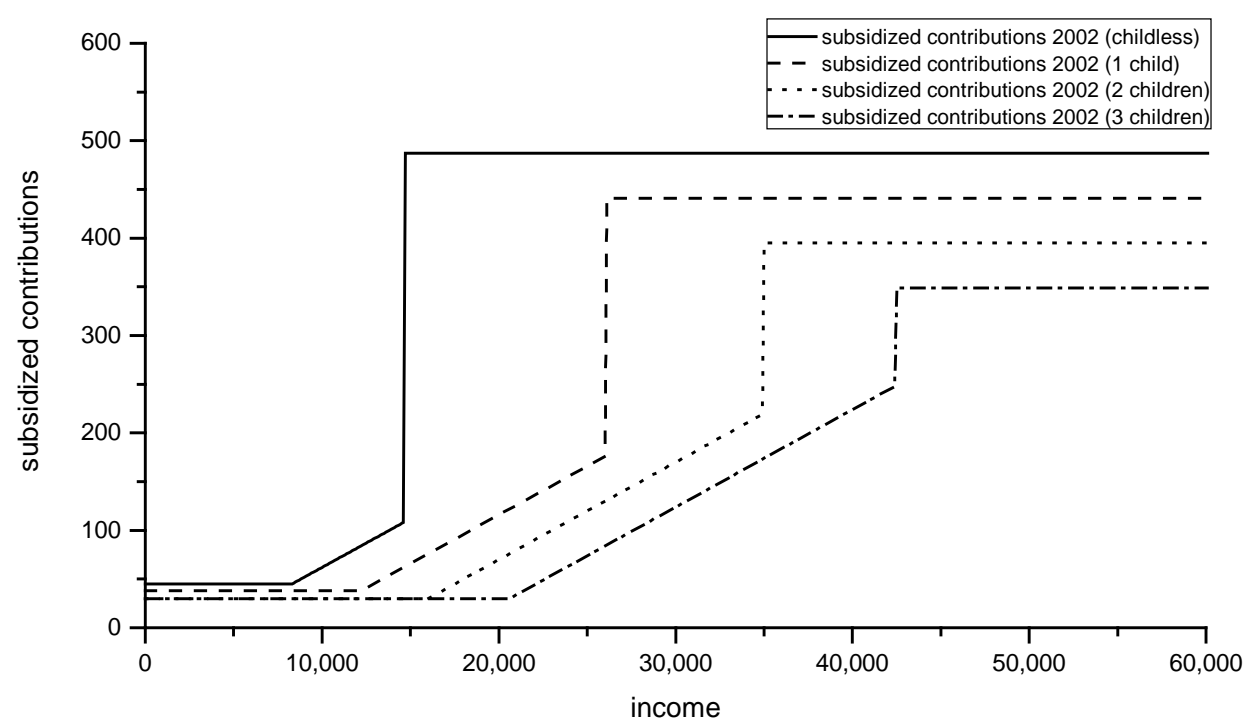

Figure 6. Maximum subsidized contributions X for different numbers of children in 2002. Source: authors' calculations.

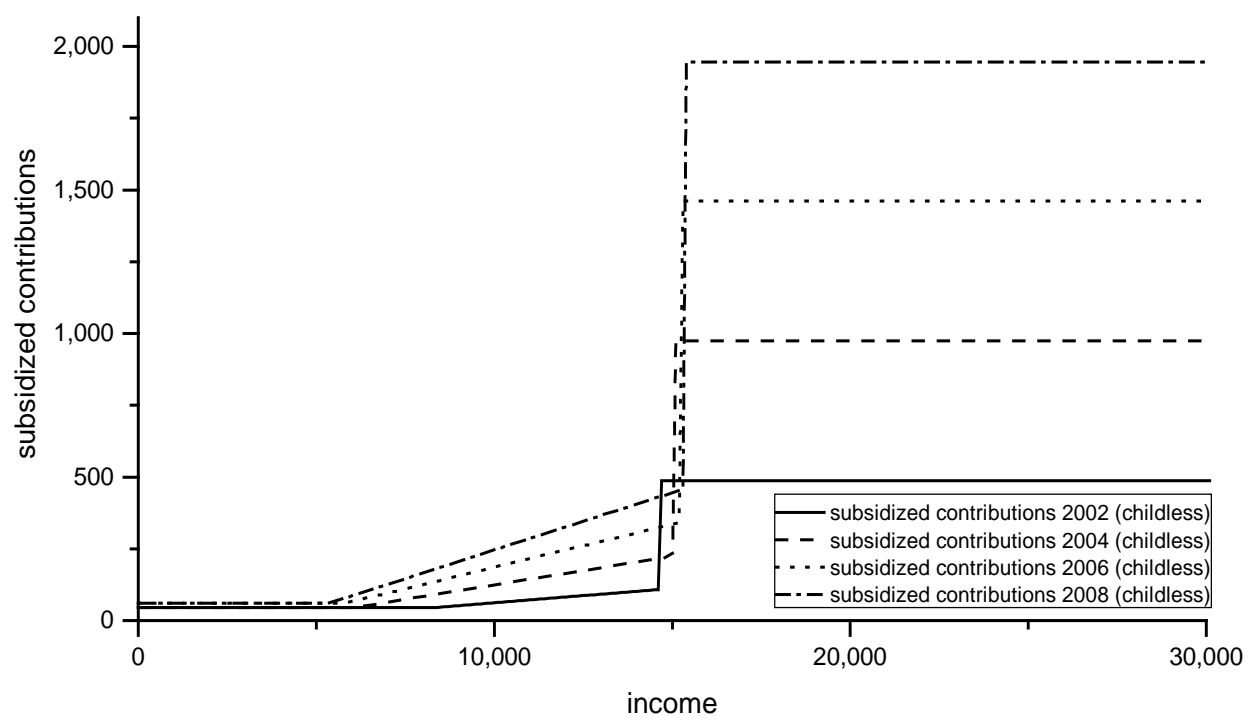

Figure 7. Maximum subsidized contributions X over time. Source: authors' calculations.

doubled to $974 €(1,050 €-76 €)$ which meant that our example taxpayer with an income of $30,000 €$ could also contribute $487 €$ to $974 €$ for a tax price of $T P<1$. In 2006, the subsidized contribution tripled to $1,461 €(1,575 €-114 €)$ and it quadrupled to $1,946 €$ $(2,100 €-154 €)$ in 2008.

In the following chapter, we take a close look at the contribution decision in our sample around the tax price kink $X$ both between different taxpayers within one year and over time.

\subsection{Data and Preliminary Evidence}

With the data of the Taxpayer-Panel, we could follow taxpayers over time. Starting with 
the dataset used in Chapter 3, our subsample used here consisted only of taxpayers contributing to a Riester contract. ${ }^{12}$ This led to a subsample ranging from 2,429 contributors in 2002 to 11,046 contributors in 2008. In our tax data, we had information about the contributed amount of both taxpayers receiving a tax deduction and those receiving a tax-free subsidy.

From 2002 to 2008, the subsidized amount increased stepwise every two years. Consequently, the subsidized amount has been quadrupled in three steps (see Table 1). So, we had years without a change in the subsidized amount (e.g. 2002/2003), and years with a change in the subsidized amount (e.g. 2003/2004). See Chapter 2 for more details.

Let us have a first look at the data. In Table 7, some descriptive statistics of the Riester contributions for the years 2002 to 2008 are displayed. As shown, the mean contribution increased in years with a governmental step and was approximately constant in the years without a step. The governmental increase over time is called "Riester Stairs". The results suggest that taxpayers followed these stairs over time. These changes in the mean contribution could be driven by different factors. For example, there could also be a shift in wages over time, resulting in a larger contributed amount. Even if we did not think that this was the driving point of the story, we cannot disprove these arguments only by interpreting means.

\subsection{Graphical Evidence}

As we have shown, we could not interpret the contributed amount of a cross-section related to the tax price because there were different locations of the tax price kink for different taxpayers. However, we can show some graphical evidence by relating the contribution decision to the tax price kink. Similar to the subsidy quota, we normalized contributions by calculating a contribution quota $C Q$ as follows:

$$
C Q_{i, t}=\frac{\text { contribution }_{i, t}}{X_{i, t}}
$$

Table 7. Descriptive statistics of Riester contributions for the years 2002 to 2008.

\begin{tabular}{ccccccccc}
\hline Year & obs. & Mean & s.d. & p5 & p25 & p50 & p75 & p95 \\
\hline 2002 & 2,429 & 346 & 950 & 30 & 112 & 260 & 480 & 958 \\
2003 & 3,321 & 369 & 438 & 30 & 120 & 276 & 487 & 1,184 \\
2004 & 4,274 & 539 & 486 & 58 & 180 & 411 & 854 & 1,215 \\
2005 & 5,693 & 566 & 530 & 60 & 180 & 466 & 920 & 1,200 \\
2006 & 7,861 & 780 & 645 & 60 & 227 & 672 & 1,260 & 1,575 \\
2007 & 10,005 & 804 & 750 & 60 & 250 & 720 & 1,284 & 1,575 \\
2008 & 11,046 & 1,041 & 768 & 70 & 360 & 958 & 1,620 & 2,100 \\
\hline
\end{tabular}

Source: Research Data Centers of the Federal Statistical Office and the Statistical Offices of the Länder, German Taxpayer-Panel, 2001-2008, authors' calculations.

${ }^{12}$ We used the same data cuts solely for the sake of consistency. The results did not differ if we did not apply the data cuts from Chapter 3. 
A $C Q<1$ meant that all contributions were subsidized and consequently the corresponding last euro tax price was before the kink. A $C Q>1$ showed that the last euro tax price was equal to one. Most importantly, if a taxpayer calibrated her contribution exactly with respect to the tax price kink, the resulting $C Q=1$. As we have argued, the maximum subsidized amount was different both for different socioeconomic factors and for different years. Consequently, a $C Q$ of around 1 seemed to result from tax planning with respect to the tax price kink.

In Figure 8, the distribution of the contribution quota of the years 2002 to 2008 are displayed. All of them look similar. There was a concentration around 1, which meant that about $20 \%$ of the taxpayers had a contribution quota from 0.95 to 1.05. Overall, there were more taxpayers with a $C Q<1$ than $>1$. Because there were both different taxpayers and different Riester regimes in the different years, the constant shape of the distribution with respect to the tax price seemed to be the result of an active management process of the contributed amount. However, individual tax planning in this figure resulted in constant distributions of the contribution quota. This means that taxpayers changed their contributions while underlying factors (individual and institutional) were changing. Because the distribution looks similar when normalized to the kink, the tax price kink seems to be the economic goal of the behavior. In Figure 9, we try to uncover the underlying change in contribution decision.

To uncover individual behavior, we tried to separate technical effects resulting from changes in tax law and behavior effects. Therefore, a synthetic contribution quota was

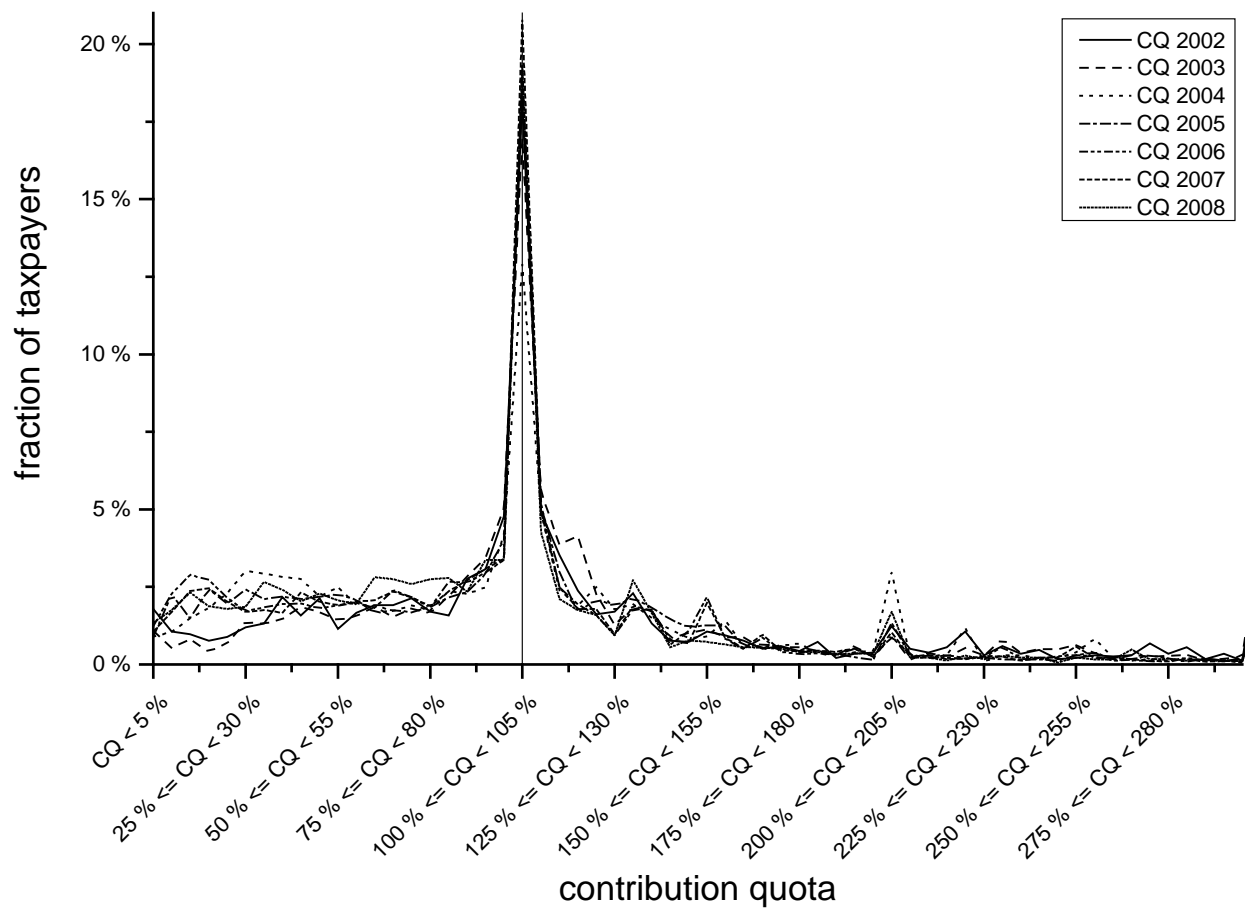

Figure 8. Distributions of the contribution quota from 2002 to 2008. Source: Research Data Centers of the Federal Statistical Office and the Statistical Offices of the Länder, German Taxpayer-Panel, 2001-2008, authors' calculations. 


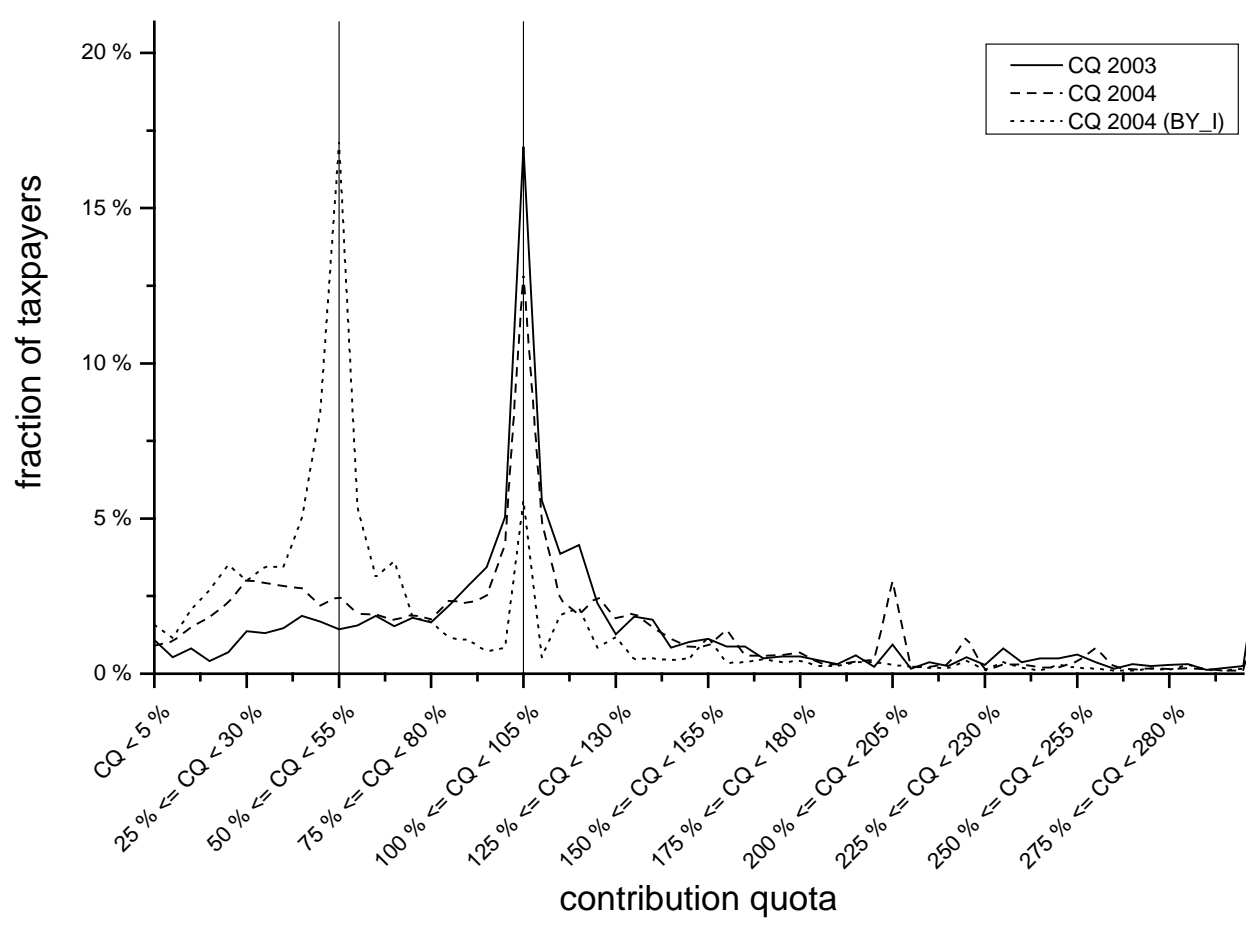

Figure 9. Distributions of the contribution quota 2003 and 2004 and synthetic contribution quota 2004. Source: Research Data Centers of the Federal Statistical Office and the Statistical Offices of the Länder, German Taxpayer-Panel, 2001-2008, authors' calculations.

calculated by applying tax law from $t$ to contribution decision from $t-1$. This synthetic quota shows the change in contribution quota solely resulting from changes in tax law without any change in individual behavior.

In our example, the distribution of the contribution quota 2004 is displayed as the dashed line in Figure 9 and follows the shape as described above with a peak around one. The synthetic contribution quota 2004 is displayed as the dotted line. We saw that if no taxpayer changed her behavior, the distribution would have shifted to the left with a peak around 0.5 . This was a result of the doubled-legislated maximum subsidized amount from 2003 to 2004. A comparison with the contribution quota 2004 revealed that there was a behavior-induced shift of the whole contribution distribution.

In Figure 10, we show all six two-year pairs that show additional evidence. In adjacent years without changes in the Riester law, we did not see behavior effects using synthetic contribution quotas. Similar to 2003/2004, in the other adjacent years with a change in Riester law we could show similar effects. Moreover, the effect size fit the size of the Riester step almost perfectly.

As we have seen, there was a change in behavior only in years with a governmental increase in the subsidized amount. The increase in contribution just fit the size of the governmental increase. So, the contribution adjustment resulted after every step in a similar distribution around a contribution quota of 1 . This let us conclude that there is a strong relation between the tax price and the contributed amount. If the tax price kink shifts, taxpayers calibrate their contribution. 

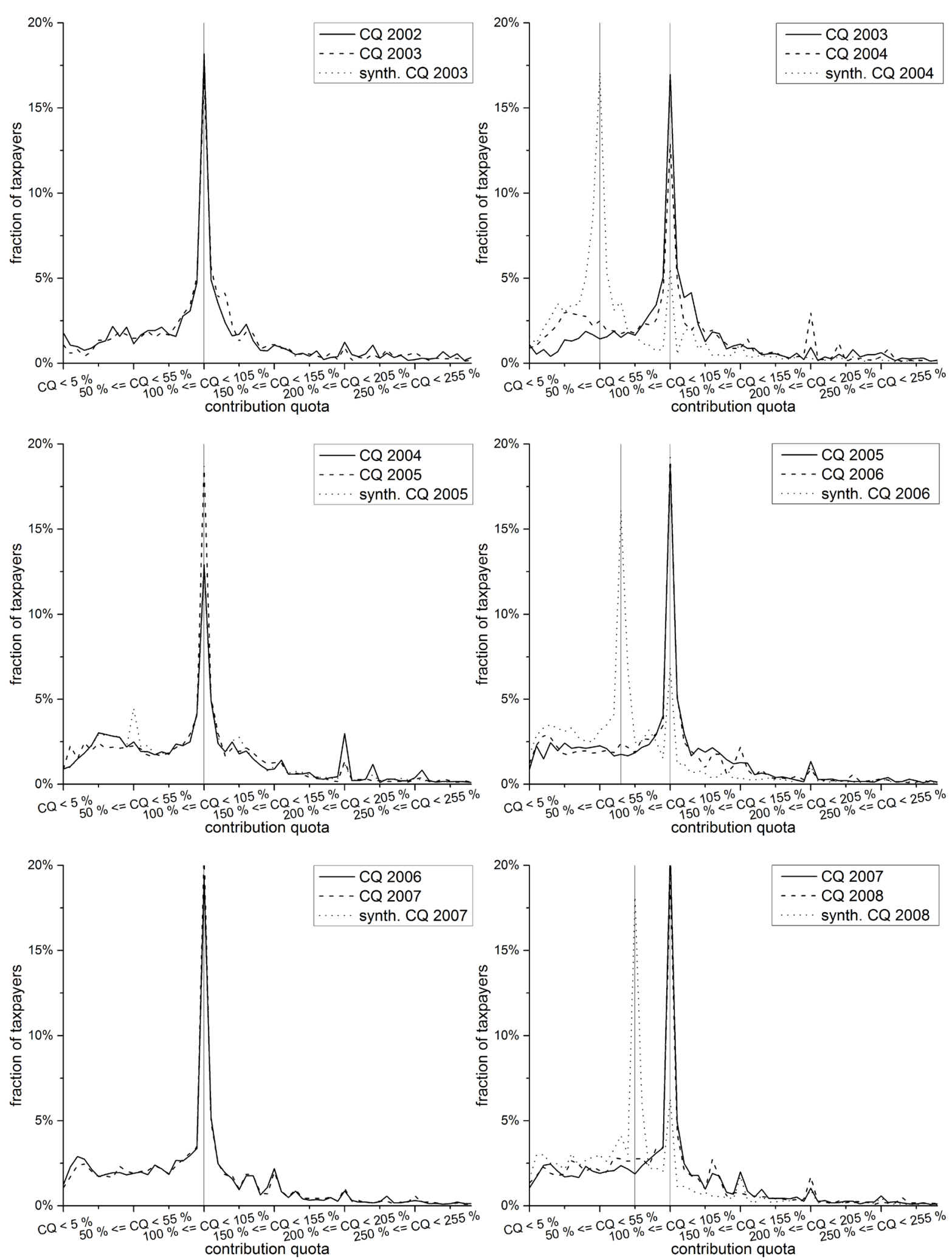

Figure 10. Distributions of the contribution quotas and corresponding synthetic contribution quota for all six two-year pairs from 2002 to 2008. Source: Research data centers of the federal statistical office and the statistical offices of the Länder, German Taxpayer-Panel, 2001-2008, authors' calculations. 
Overall, it can be stated that the government has control over the contributed amount. A shift in the maximum subsidized amount resulted in an immediate shift in individual savings. This can be interpreted as a successful rule to reach the governmental goal. On the other hand, the observed immediate reaction was a result of the very high subsidy generating tax price kinks where the tax price switched in mean from 0.51 to 1. Assuming future consumption to be a normal good, the kink structure of the tax price would lead to huge welfare losses. In other words: if the after-tax price were designed as a decreasing function of savings, we would assume welfare gains. So, the government has control over the contributed amount using an effective but expensive scheme.

\section{Summary}

Increasing life spans and declining birth rates of the last decades have been generating a funding gap of the traditional pay-as-you-go system. To close this gap, Germany introduced the Riester Scheme in 2002. For this voluntary private pension, the government grants one of the most generous tax subsidies. Consequently, the success of the retirement reform depends on the acceptance of private pensions and therefore on the effects of tax-based saving incentives on contribution behavior. In this paper, the effects of the subsidy on two different decisions were analyzed.

First, we regressed the tax price of the first euro contributed and the income after taxes against the decision of whether or not to contribute. There we got at least three results: First, our central estimate of -0.14 implied a local average marginal elasticity of the contribution decision with respect to tax price of -2.36 . Second, with our identification strategy, the decision was driven mainly by price effects and not by other socioeconomic characteristics such as the number of children. Third, the income effect seemed not to have an influence on the decision.

Second, we showed graphical evidence for the decision on how much to contribute using price kinks. The location of the price kink was different both for different taxpayers and for different years. Therefore, we analyzed the distribution of contributions normalized to the price kink (contribution quota) using variations of the Riester Scheme over time. This showed us two things: First, we saw that most of our contributors (about $20 \%$ ) contributed exactly on the price kink and therefore contributed exactly the subsidized amount. Second, the shifts in the location of the price kink resulted in the same (normalized to the kink) distribution. This led us to conclude that the decision on the intensive margin is very tax sensitive.

Overall, it can be stated that government has control over contribution behavior. Taxpayers showed strong responses on both margins. However, the question of whether this led to an increase in the overall savings of the household cannot be answered with our tax data. If we assume no effect on the saving rate, the results can be interpreted as a substitution effect between savings where the taxpayer is free to dispose and a contract where the rules are controlled by government. 


\section{Acknowledgements}

The authors gratefully acknowledge the Research Data Centers of the Federal Statistical Office and the Statistical Offices of the Länder for providing the dataset and great support.

\section{References}

[1] Eichhorst, W., Gerard, M., Kendzia, M.J., Mayrhuber, C., Nielsen, C., Rünstler, G. and Url, T. (2011) Pension System in the EU-Contingent Liabilities and Assets in the Public and Private Sector. IZA Research Report No. 42.

[2] Federal Ministry of Labor and Social Affairs (2014) Rentenversicherungsbericht 2014. http://www.bmas.de/DE/Themen/Rente/Rentenversicherungsbericht/inhalt.html

[3] Yoo, K.-Y. and de Serres, A. (2004) Tax Treatment of Private Pension Savings in OCDE Countries. OECD Economic Studies, 2004, 73-110.

[4] OECD (2013) Pensions at a Glance 2013: OECD and G20 Indicators. OECD Publishing, European Union.

[5] Kiesewetter, D. (2002) Für wen lohnt sich die Riester-Rente? Corporate Finance Biz, 4, 101-110.

[6] Börsch-Supan, A., Reil-Held, A. and Schunk, D. (2006) Das Sparverhalten deutscher Haushalte: Erste Erfahrungen mit der Riester-Rente. MEA Discussion Paper No. 114-06.

[7] Pfarr, C. and Schneider, U. (2011) Anreizeffekte und Angebotsinduzierung im Rahmen der Riester-Rente: Eine empirische Analyse geschlechts- und sozialisationsbedingter Unterschiede. Perspektiven der Wirtschaftspolitik, 12, 27-46. http://dx.doi.org/10.1111/j.1468-2516.2010.00349.x

[8] Pfarr, C. and Schneider, U. (2013) Choosing between Subsidised or Unsubsidised Private Pension Schemes: Evidence from German Panel Data. Journal of Pension Economics and Finance, 12, 62-91. http://dx.doi.org/10.1017/S1474747212000170

[9] Corneo, G., Keese, M. and Schröder, C. (2009) The Riester Scheme and Private Savings: An Empirical Analysis Based on the German SOEP. Schmollers Jahrbuch: Journal of Applied Social Science Studies, 129, 321-332. http://dx.doi.org/10.3790/schm.129.2.321

[10] Corneo, G., Keese, M. and Schröder, C. (2011) The Effect of Saving Subsidies on Household Savings: Evidence from Germany. Ruhr Economic Papers No. 170.

[11] Schmidt, T.-P. (2013) Ein Mikrosimulationsmodell zur Berechnung der einkommensteuerlichen Bemessungsgrundlage und der Steuerzahlung auf Basis des Taxpayer-Panels. FDZ-Arbeitspapier No. 45.

[12] Börsch-Supan, A. and Wilke, C.B. (2004) The German Public Pension System: How It Was, How It Will Be. NBER Working Paper 10525.

[13] Kriete-Dodds, S. (2008) Staatliche Förderung der Riester-Rente für das Jahr 2003. Wirtschaft und Statistik, 60, 60-68.

[14] Jung, A. and Thöne, M. (2009) Förderung der privaten kapitalgedeckten Altersvorsorge (Riester-Rente) durch Zulagen. In: Finanzwissenschaftliches Forschungsinstitut an der Universität zu Köln (FiFo Köln), Copenhagen Economics ApS and Zentrum für Europäische Wirtschaftsforschung (ZEW), Eds., Evaluierung von Steuervergünstigungen, Vol. 3, Evaluierungsberichte, Zweiter, 401-473.

[15] Kriete-Dodds, S. and Vorgrimler, D. (2007) European Data Watch: The German TaxpayerPanel. Schmollers Jahrbuch: Journal of Applied Social Science Studies, 127, 497-509. 
[16] Gerber, U. and Hammer, S. (2013) Das Taxpayer-Panel 2001 Bis 2008. Wirtschaft und Statistik, 65, 729-737.

[17] Moffitt, R.A. and Wilhelm, M.O. (2000) Taxation and the Labor Supply Decisions of the Affluent. In: Slemrod, J.B., Ed., Does Atlas Shrug? The Economic Consequences of Taxing the Rich, Russell Sage Foundation Books at Harvard University Press, Cambridge, 193-234.

[18] Heim, B.T. and Lurie, I.Z. (2012) The Effect of Recent Tax Changes on Tax-Preferred Saving Behavior. National Tax Journal, 65, 283-312. http://dx.doi.org/10.17310/ntj.2012.2.02

[19] Gruber, J. and Saez, E. (2002) The Elasticity of Taxable Income: Evidence and Implications. Journal of Public Economics, 84, 1-32. http://dx.doi.org/10.1016/S0047-2727(01)00085-8

[20] Pfarr, C. and Schneider, U. (2012) Riester-Rente: (K)ein Kinderspiel! Vierteljahrshefte zur Wirtschaftsforschung, 81, 181-198. http://dx.doi.org/10.3790/vjh.81.2.181

[21] Rick, A. (2011) The Saving Behavior of German Families: Heterogeneity in the Effect of Children On Annual Saving, Saving Motives, and the Regularity of Saving. MEA Studies No. 11.

[22] Bucher-Koenen, T. and Lusardi, A. (2011) Financial Literacy and Retirement Planning in Germany. Journal of Pension Economics and Finance, 10, 565-584. http://dx.doi.org/10.1017/S1474747211000485

[23] Auten, G. and Carroll, R. (1999) The Effect of Income Taxes on Household Income. Review of Economics and Statistics, 81, 681-693. http://dx.doi.org/10.1162/003465399558409

[24] Gelber, A.M. (2014) Taxation and the Earnings of Husbands and Wives: Evidence from Sweden. Review of Economics and Statistics, 96, 287-305. http://dx.doi.org/10.1162/REST_a_00425

[25] Wooldridge, J.M. (2013) Introductory Econometrics: A Modern Approach. Cengage Learning Emea, Andover.

[26] Stock, J.H. and Watson, M.W. (2011) Introduction to Econometrics. Pearson, Boston.

[27] Angrist, J.D. and Pischke, J.-S. (2009) Mostly Harmless Econometrics. Princeton University Press, Princeton.

[28] Wooldridge, J.M. (2010) Econometric Analysis of Cross Section and Panel Data. The MIT Press, London.

[29] Stock, J.H., Wright, J.H. and Yogo, M. (2002) A Survey of Weak Instruments and Weak Identification in Generalized Method of Moments. Journal of Business and Economic Statistics, 20, 518-529. http://dx.doi.org/10.1198/073500102288618658

[30] Mood, C. (2010) Logistic Regression: Why We Cannot Do What We Think We Can Do, and What We Can Do about It. European Sociological Review, 26, 67-82. http://dx.doi.org/10.1093/esr/jcp006

[31] Chetty, R., Friedman, J.N., Olsen, T. and Pistaferri, L. (2011) Adjustment Costs, Firm Responses, and Micro vs. Macro Labor Supply Elasticities: Evidence from Danish Tax Records. Quarterly Journal of Economics, 126, 749-804. http://dx.doi.org/10.1093/qje/qjr013

[32] Chetty, R., Looney, A. and Kroft, K. (2009) Salience and Taxation: Theory and Evidence. American Economic Review, 99, 1145-1177. http://dx.doi.org/10.1257/aer.99.4.1145 
Submit or recommend next manuscript to SCIRP and we will provide best service for you:

Accepting pre-submission inquiries through Email, Facebook, LinkedIn, Twitter, etc. A wide selection of journals (inclusive of 9 subjects, more than 200 journals)

Providing 24-hour high-quality service

User-friendly online submission system

Fair and swift peer-review system

Efficient typesetting and proofreading procedure

Display of the result of downloads and visits, as well as the number of cited articles

Maximum dissemination of your research work

Submit your manuscript at: http://papersubmission.scirp.org/

Or contact me@scirp.org 